\title{
Motivasi Belajar Bahasa Mandarin Murid Kelas II SMP Sekolah Minggu Buddha Maitreya Medan
}

\author{
Elly Romy \\ STBA-PIA, Medan, Sumatera Utara \\ ellyromy168@gmail.com \\ Nuryadi \\ STBA-PIA, Medan, Sumatera Utara
}

\begin{abstract}
Abstrak
This research was aimed at explaining the learning motivation of the second grade of Junior High School students at Sekolah Minggu Buddha Maitreya Medan in learning Mandarin. Besides, the goal of this research was to describe the factors that influence their learning motivation. This study was conducted by using descriptive qualitative design. The subjects of this study was 20 students of the second grade of Junior High School students at Sekolah Minggu Buddha Maitreya. Motivation is divided into intrinsic and extrinsic motivation. Thus, the study of the students' learning motivation was separated according to the type of motivation. The results showed that there were about 8 students that had intrinsic motivation, while there were about 11 students that had extrinsic motivation. The factors that underlie this finding was due to the difficulty that the students faced in learning Mandarin.
\end{abstract}

Keywords: learning motivation, Mandarin, extrinsic, intrinsic

\section{Pendahuluan}

Persoalan belajar sebagai budaya yang terus berkembang, tidak bisa di pisahkan dengan pemaknaan hakikat manusia, baik yang belajar maupun yang membelajarkan. Secara tersirat persoalan-persoalan itu mestinya menjadikan rujukan dalam membahas masalah-masalah belajar. Wasty Soemanto (2006:173) menyatakan bahwa Dunia dimana kita hidup ini membutuhkan manusia yang diperlengkapi keterampilan-keterampilan untuk memecahkan masalah-masalah kehidupan nyata. Keterampilan tersebut didapat sejak dini baik melalui jenjang pendidikan formal maupun non-formal. Melalui pendidikan formal, keterampilan dan pembelajaran yang diperoleh oleh para siswa di sekolah dapat menjadi bekal bagi mereka setelah mereka memasuki dunia pekerjaan atau dunia kehidupan dimasa mendatang.

Keberahasilan dalam seberapa banyak pembelajaran dan keterampilan yang dapat diperoleh seorang siswa tidak terlepas dari faktor internal yaitu motivasi. Sardiman 
(2011:40) menyatakan motivasi seseorang akan berhasil dalam belajar, kalau pada dirinya sendiri ada keinginan untuk belajar.

Menurut McDonald (kutipan sardiman, 2011:74) menyatakan motivasi akan menyebabkan terjadinya suatu perubahan energi yang ada pada diri manusia, sehingga akan bergayut dengan persoalan gejala kejiwaan, perasaan dan juga emosi, untuk kemudian bertindak atau melakukan sesuatu. Semua ini didorong karena adanya tujuan, kebutuhan atau keinginan. Lebih lanjut, McDonald (kutipan sardiman, 2011:74) menyatakan bahwa motivasi adalah perubahan energi dalam diri seseorang yang ditandai dengan munculnya "feeling" dan didahului dengan tanggapan terhadap adanya tujuan. Dari pengertian yang dikemukakan Mc. Donald ini mengandung tiga elemen penting: (1) Motivasi itu mengawali terjadinya perubahan energi pada diri setiap individu manusia; (2) Motivasi ditandai dengan munculnya, "feeling", efeksi seseorang yang mempengaruhi persoalan kejiwaan, efeksi dan emosi; Motivasi merupakan respons dari suatu aksi, yakni tujuan.

Menurut Istarani dan Intan pulungan (2015:59) Pada prinsipnya motivasi terdiri dari dua, yaitu motivasi intrinsik yaitu motivasi yang berasal dari dalam diri sendiri dan selanjutnya adalah motivasi ekstrensik yang muncul dari pengaruh luar individu. Menurut Darsono (2000:65), motivasi dipengaruhi faktor internal dan eksternal. Faktor internal meliputi cita-cita atau aspirasi siswa, kemampuan belajar, dan kondisi siswa. Sementara faktor eksternal yang mempengaruhi motivasi adalah londisi lingkungan, unsur-unsur dinamis dalam belajar, dan upaya guru dalam pembelajaran siswa.

Oemar Hamalik (2010:161) menyatakan nilai motivasi dalam Pengajaran menjadi tanggung jawab guru agar pengajaran yang diberikannya berhasil dengan baik. Selain itu, selain memastikan pengajaran yang diberikan efektif, seorang guru juga harus memastikan jika muridnya melalui proses belajar yang baik. M.Thobroni (2015:16) menyatakan belajar merupakan proses yang bersifat internal yang tidak dapat dilihat dengan nyata. Meski belajar merupakan proses yang bersifat internal, hasil belajar adalah sesuatu yang dapat dilihat dan dinilai. Purwanto (2011:54) menyatakan hasil belajar sebagai perubahan perilaku yang terjadi setelah mengikuti proses belajar mengajar sesuai dengan tujuan pendidikan. Jadi, sekalipun pada prosesnya belajar tidak secara langsung dapat terlihat, hasil dari proses tersebut dapat diketahui melalui perubahan yang ditunjukkan sesuai proses itu berlangsung. 


\section{Metode}

Penelitian ini dilaksanakan secara kualitatif dengan merujuk pada Moleong (2010:6) yang mendefinisikan penelitian kualitatif sebagai penelitian yang bermaksud untuk memahami fenomena tentang apa yang dialami subjek penelitian misalnya perilaku, persepsi, motivasi, tindakan dll, dengan deskripsi dalam bentuk kata-kata dan bahasa, pada suatu konteks khusus yang alamiah dan dengan memanfaatkan berbagai metode alamiah.

Subjek penelitian dalam penelitian ini adalah siswa kelas II SMP Sekolah Minggu Buddha Maitreya Medan yang berlokasi di Jalan Cemara Boulevard Utara No.8 Komplek Perumahan Cemara Asri. Penentuan penelitian dilakukan dengan teknik purposive sampling. Penelitian yang digunakan penulis adalah kelas II SMP, dimana terdapat 2 kelas dan penulis mengambil penelitian di kelas pertama yang dianggap memiliki motivasi yang tergolong rendah. Total keseluruhan populasi yang berada di kelas adalah sebanyak 20 siswa.

Pengumpulan data dilakukan dengan melakukan observasi dan interview yang kemudian akan dianalisis menggunakan teori Miles \& Huberman (2014:31) dengan rancangan langkah-langkah:

1) Reduksi Data. Merupakan bentuk analisis yang menajamkan, menggolongkan, mengarahkan, membuang yang tidak perlu, dan menorganisasi data dengan cara tertentu sehingga simpulan akhir dapat ditarik.

2) Penyajian Data. Tahap untuk menampilkan informasi tersusun yang memberi kemungkinan adanya penarikan kesimpulan dan pengambilan tindakan.

3) Penarikan Kesimpulan. Langkah ini dilakukan secara induktif, yaitu teknik penarikan kesimpulan dari data-data yang bersifat khusus menuju kesimpulan yang bersifat umum. 
Hasil

Motivasi Belajar bahasa Mandarin Siswa Kelas II SMP Sekolah Minggu Buddha Maitreya Medan

Table 3.1. Motivasi Intrinsik untuk Belajar Bahasa Mandarin Siswa Kelas II SMP Sekolah Minggu Buddha Maitreya Medan

\begin{tabular}{|c|c|c|c|c|c|c|}
\hline $\begin{array}{l}\text { Responde } \\
\mathrm{n}\end{array}$ & P.1 & Jawaban & P. 2 & $\begin{array}{l}\text { Jawaba } \\
\mathrm{n}\end{array}$ & P.3 & $\begin{array}{l}\text { Jawab } \\
\text { an }\end{array}$ \\
\hline 1 & \multirow{20}{*}{$\begin{array}{l}\text { Pernahkah } \\
\text { adik } \\
\text { belajar } \\
\text { bahasa } \\
\text { Mandarin } \\
\text { dipaksa } \\
\text { guru? }\end{array}$} & Tidak & \multirow{20}{*}{$\begin{array}{l}\text { Pernahka } \\
\text { h adik } \\
\text { pernah } \\
\text { pinjam } \\
\text { buku } \\
\text { mandarin } \\
\text { di } \\
\text { perpustak } \\
\text { aan? }\end{array}$} & Pernah & \multirow{20}{*}{$\begin{array}{l}\text { Pernahkah } \\
\text { adik nonton } \\
\text { TV } \\
\text { mandarin di } \\
\text { rumah? }\end{array}$} & Pernah \\
\hline 2 & & Pernah & & Pernah & & Pernah \\
\hline 3 & & Pernah & & Pernah & & Pernah \\
\hline 4 & & Tidak & & Tidak & & Pernah \\
\hline 5 & & Tidak & & Pernah & & Pernah \\
\hline 6 & & Pernah & & Pernah & & Pernah \\
\hline 7 & & Pernah & & Tidak & & Pernah \\
\hline 8 & & Tidak & & Pernah & & Tidak \\
\hline 9 & & Pernah & & Pernah & & Tidak \\
\hline 10 & & Pernah & & Tidak & & Pernah \\
\hline 11 & & Pernah & & Tidak & & Pernah \\
\hline 12 & & Perna & & Tidak & & Pernah \\
\hline 13 & & Tidak & & Tidak & & Tidak \\
\hline 14 & & Pernah & & Tidak & & Tidak \\
\hline 15 & & Pernah & & Tidak & & Tidak \\
\hline 16 & & Pernah & & Tidak & & Tidak \\
\hline 17 & & Tidak & & Tidak & & Tidak \\
\hline 18 & & Tidak & & Tidak & & Pernah \\
\hline 19 & & Pernah & & Tidak & & Pernah \\
\hline 20 & & Pernah & & Tidak & & Pernah \\
\hline
\end{tabular}

Untuk pertanyaan wawancara yang pertama diketahui bahwa 9 orang atau kurang dari 50\% responden memiliki motivasi intrinsik. Untuk pertanyaan wawancara yang kedua diketahui ada 7 orang atau kurang dari $35 \%$ responden yang memiliki motivasi intrinsik. Sedangkan, untuk pertanyaan wawancara yang ketiga diketahui 9 orang atau kurang dari $50 \%$ responden memiliki motivasi intrinsik.

Sedangkan untuk motivasi extrinsik terangkum dalam tabel di bawah ini sesuai dengan pertanyaan wawancara berikut ini: 
Table 3.2. Motivasi Extrinsik untuk Belajar Bahasa Mandarin Siswa Kelas II SMP Sekolah Minggu Buddha Maitreya Medan

\begin{tabular}{|c|c|c|c|c|c|c|}
\hline $\begin{array}{l}\text { Respond } \\
\text { en }\end{array}$ & P.1 & $\begin{array}{l}\text { Jawa } \\
\text { ban }\end{array}$ & P. 2 & $\begin{array}{l}\text { Jawaba } \\
\mathrm{n}\end{array}$ & P.3 & $\begin{array}{l}\text { Jawaba } \\
n\end{array}$ \\
\hline 1 & \multirow{20}{*}{$\begin{array}{l}\text { Menurut } \\
\text { adik } \\
\text { Belajar } \\
\text { bahasa } \\
\text { Mandari } \\
\text { n itu } \\
\text { sulit? }\end{array}$} & Ya & \multirow{20}{*}{$\begin{array}{l}\text { Apakah } \\
\text { adik suka } \\
\text { belajar } \\
\text { bahasa } \\
\text { Mandarin } \\
\text { ? }\end{array}$} & Tidak & \multirow{20}{*}{$\begin{array}{l}\text { Apakah } \\
\text { Belajar } \\
\text { bahasa } \\
\text { mandarin } \\
\text { bisa } \\
\text { mendatangka } \\
\text { n motivasi } \\
\text { adik? }\end{array}$} & $\mathrm{Ya}$ \\
\hline 2 & & Tidak & & Tidak & & $\mathrm{Ya}$ \\
\hline 3 & & $\mathrm{Ya}$ & & $\mathrm{Ya}$ & & Tidak \\
\hline 4 & & $\mathrm{Ya}$ & & Ya & & $\mathrm{Ya}$ \\
\hline 5 & & $\mathrm{Ya}$ & & $\mathrm{Ya}$ & & Tidak \\
\hline 6 & & $\mathrm{Ya}$ & & $\mathrm{Ya}$ & & $\mathrm{Ya}$ \\
\hline 7 & & Tidak & & $\mathrm{Ya}$ & & $\mathrm{Ya}$ \\
\hline 8 & & Tidak & & Tidak & & Tidak \\
\hline 9 & & Tidak & & Tidak & & Tidak \\
\hline 10 & & $\mathrm{Ya}$ & & $\mathrm{Ya}$ & & Tidak \\
\hline 11 & & $\mathrm{Ya}$ & & $\mathrm{Ya}$ & & $\mathrm{Ya}$ \\
\hline 12 & & $\mathrm{Ya}$ & & $\mathrm{Ya}$ & & $\mathrm{Ya}$ \\
\hline 13 & & Tidak & & Tidak & & Tidak \\
\hline 14 & & Tidak & & Tidak & & $\mathrm{Ya}$ \\
\hline 15 & & Tidak & & Tidak & & Tidak \\
\hline 16 & & Tidak & & Tidak & & Tidak \\
\hline 17 & & Tidak & & Tidak & & Tidak \\
\hline 18 & & $\mathrm{Ya}$ & & $\mathrm{Ya}$ & & $\mathrm{Ya}$ \\
\hline 19 & & $\mathrm{Ya}$ & & $\mathrm{Ya}$ & & $\mathrm{Ya}$ \\
\hline 20 & & $\mathrm{Ya}$ & & $\mathrm{Ya}$ & & $\mathrm{Ya}$ \\
\hline
\end{tabular}

Dari pertanyaan pertama wawancara di atas, diketahui bahwa 9 orang, atau kurang dari $45 \%$ responden memiliki motivasi extrinsik yakni terkait dengan kesulitan belajar bahasa Mandarin. Terkait dengan kesukaan murid untuk belajar bahasa Mandarin seperti pada pertanyaan wawancara kedua diketahui bahwa ada 11 orang atau kurang dari 55\% responden yang memiliki motivasi extrinsik. Dari pertanyaan penelitian yang ketiga terkait dengan dampak dari pembelajaran bahasa Mandarin terhadap motivasi peserta didik diketahui ada 12 orang aatu kurang dari 50\% responden yang memiliki motivasi extrinsik.

Faktor-faktor yang Mempengaruhi Motivasi Belajar bahasa Mandarin Siswa Kelas II SMP Sekolah Mnggu Buddha Maitreya Medan

Secara teoritis, Darsono (2000:65) menyatakan ada beberapa faktor yang mempengaruhi motivasi belajar: (a) faktor internal, yaitu faktor yang ada dalam diri sendiri yang mencakup: cita-cita atau aspirasi siswa, kemampuan belajar, kondisi siswa; (b) faktor eksternal, yaitu yang ada diluar yang terdiri: kondisi lingkungan, unsur-unsur dinamis dalam belajar, upaya guru dalam pembelajaran siswa. 
Secara empiris, berdasarkan hasil data wawancara ditemukan bahwa ada 25 responden yang dikategorikan sebagai pembelajar dengan motivasi intrinsik, sedangkan untuk pembelajar dengan motivasi extrinsik ada 32 responden. Hal ini disebabkan oleh faktor kemampuan siswa dalam mengikuti pelajaran bahasa Mandarin yakni ada 11 orang responden yang mengatakan bahwa pelajaran tersebut sulit untuk dimengerti.

\section{Pembahasan}

Dari hasil wawancara dan analisis data diperoleh bahwa lebih dari 50\% siswa tidak memiliki motivasi intrinsik dalam belajar bahasa mandarin. Mereka lebih cenderung dipengaruhi oleh motivasi extrensik karena ada dorongan dan motivasi dari guru supaya murid mau belajar, selain itu juga karena murid hanya sekedar mematuhi perintah guru.

Dari hasil analisis data diketahui bahwa faktor external dari siswa sendiri masih kurang, sebagian besar dari mereka berpendapat bahwa bahasa mandarin tidak berpengaruh besar terhadap cita-cita mereka. Kemudian kemampuan belajar siswa juga masih kurang dalam menerima pelajaran bahasa mandarin, dan kondisi lingkungan yang tidak nyaman juga membuat siswa tidak nyaman untuk belajar bahasa mandarin, meskipun sudah ada upaya-upaya dari guru untuk memberikan dorongan dan motivasi belajar, tapi sebagian besar murid masih menggangap belajar bahasa mandarin itu sulit.

\section{Referensi}

A.M. Sardiman. (2011). Interaksi dan Motivasi Belajar Mengajar. Jakarta: Rajawali Press.

Darsono, Max. dkk. (2000). Belajar dan Pembelajaran. Semarang: IKIP Semarang Press.

Hamalik, Oemar. (2010). Proses Belajar Mengajar. Jakarta: PT Bumi Aksara.

Istarani \& Intan Pulungan. (2015). Ensiklopedi Pendidikan Jilid 1. Medan : Media Persada.

M. Thobroni. (2015). Belajar dan Pembelajaran: Teori dan Praktek. Yogjakarta: Arr-Ruzz Media.

Miles, M.B., Huberman, A.M. (2014). Qualitative Data Analysis. London: SAGE Publications, Inc.

Moleong, L.J. (2010). Metodologi Penelitian Kualitatif, Bandung: Remaja Rosda Karya. 
Purwanto. (2011). Evaluasi Hasil Belajar. Yogyakarta: Pustaka Pelajar.

Soemanto, Wasty.(2006). Psikologi Pendidikan: Landasan Kerja Pemimpin Pendidikan.Jakarta: Rineka Cipta 